\title{
RADIOTHYROXINE TURNOVER STUDIES IN MYXEDEMA, THYROTOXICOSIS, AND HYPERMETABOLISM WITHOUT ENDOCRINE DISEASE
}

\section{BY KENNETH STERLING AND ROBERT B. CHODOS}

\author{
(From the Department of Medicine, State University of New York, Upstate Medical Center, \\ Syracuse, and the Radioisotope Unit, Veterans Administration Hospital, \\ Syracuse, $N . Y$.)
}

(Submitted for publication February 8, 1956; accepted March 15, 1956)

In a previous report (1) the disappearance curves of I ${ }^{131}$-labeled L-thyroxine and L-triiodothyronine were described in euthyroid subjects. The radioactive compounds were injected intravenously, and the radioactivity of the plasma or serum was determined at intervals for approximately two weeks. Estimations were made of the rate of degradation of organic (thyroxine) iodine. In the present work, this approach has been extended to myxedematous and thyrotoxic patients with findings agreeing in general with Ingbar and Freinkel (2) whose methods were similar, as well as Berson and Yalow (3) who employed entirely different methods. In the effort to elucidate the role of peripheral tissue metabolism in hormone degradation rate, studies were carried out during treatment of myxedema, and in subjects exhibiting hypermetabolism without evidence of endocrine disease.

\section{MATERIAL AND METHODS}

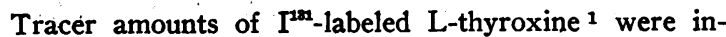
jected intravenously, and heparinized venous blood samples were taken $10^{\prime}$ minutes after injection and daily or on alternate days for two weeks or longer. Prior to injection the radiothyroxine was kept in siliconed glassware and syringes to prevent adsorption by vessel walls. The plasma radioactivity was assayed in a well-type scintillation counter which recorded approximately one million counts per minute per microcurie of $\mathrm{I}^{120}$ (42 per cent overall efficiency) above a background of $130 \mathrm{cpm}$. Corrections for radioactive decay were made when necessary. Usually all plasma samples from a given patient and diluted aliquots of the administered compound were counted together after conclusion of the study, obviating the need for decay correction.

In all subjects one or more plasma protein bound iodine (PBI) or butanol extractable iodine (BEI) de-

1 Approximately $50 \mu \mathrm{c}$. in 2 to $10 \mu \mathrm{g}$. thyroxine, supplied by Abbott Laboratories, Oak Ridge, Tennessee. terminations were carried out ${ }^{2}(4,5)$. The BEI was done to avoid interference from inorganic iodine previously administered in the three instances where this had occurred. The two determinations were used interchangeably in the calculations of "organic iodine" figures; PBI ordinarily exceeds BEI by approximately $0.6 \mu \mathrm{g}$. per cent in the absence of inorganic iodine (5).

\section{Calculations}

The injection of radiothyroxine was followed by a relatively rapid initial fall in radioactivity of the plasma (Figure 1). This was attributed to diffusion of the tracer out of the vascular compartment as it was distributed throughout the body's extrathyroidal organic iodine (EOI) pool. After two days the plasma radioactivity declined more gradually, resulting in a straight line when plotted semilogarithmically. This slow exponential component of the disappearance curve was interpreted as

RADIOTHYROXINE DISAPPEARANCE CURVE

CONTROL SUBJECT R, R. GIVEN IODINE, DURING LATTER PART OF STUDY

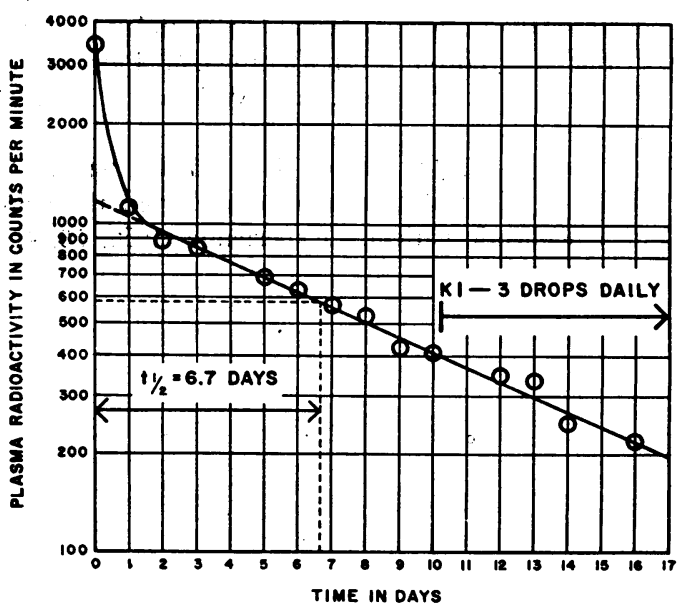

Figure 1

Semilogarithmic plot.

2 Performed by Bio-Science Laboratories, 2231 South Carmelina Avenue, Los Angeles 64, California and in some instances by Dr. Belton A. Burrows, Veterans Administration Hospital, Boston, Mass. 


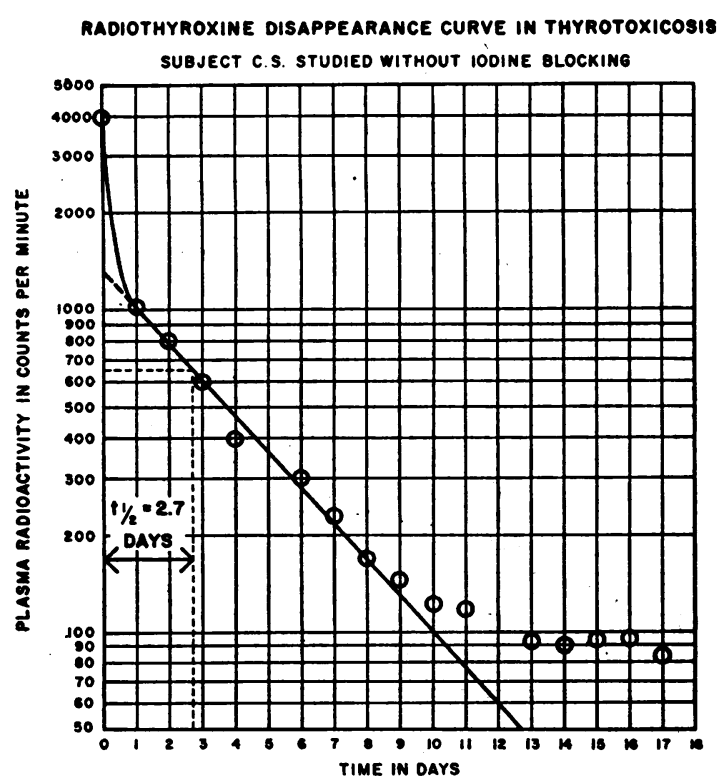

Figure 2

Semilogarithmic plot. The flattening of the curve after the eighth day was attributed to reutilization of the $I^{\text {ma }}$ label from degraded radiothyroxine and its reappearance in the circulation as newly synthesized radiothyroxine. With iodine prefeeding, the curves remained linear throughout in thyrotoxic patients.

metabolic degradation of the administered radiothyroxine, hence a measure of the turnover rate of the hormone.

The half-time of thyroxine turnover was obtained graphically from the linear component of the disappearance curve extrapolated back to zero time (Figure 1). The turnover rate was computed from the half-time. ${ }^{3}$

As an example, the calculations for subject $R$. $R$. follow :

Half-time $\left(t_{\xi}\right)=6.7$ days (obtained graphically. Figure 1 ).

Turnover rate $(k)=\frac{\ln 2}{t_{i}}=\frac{0.693}{6.7}=0.104$

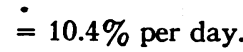

This turnover rate indicated the fraction of the body's extrathyroidal organic iodine (EOI) pool synthesized and

${ }^{3}$ The relation $k=\frac{\ln 2}{t_{k}}$ may be derived from the equation for exponential decay:

where:

$$
A=A_{0} e^{-k t}
$$

A $=$ Radiothyroxine at any time

$A_{0}=$ Radiothyroxine at zero time

$t=$ Time in days

$\mathbf{t}_{\mathbf{i}}=$ Half-time

$k=$ Turnover rate as fraction of the body's extrathyroidal organic iodine pool turned over per day. This is conveniently expressed as per cent per day. degraded daily. The EOI pool was estimated from the quotient

$$
\frac{\text { Total radioactivity injected }}{\text { Radioactivity per microgram of } \mathrm{PBI}} \text {. }
$$

The denominator was obtained from the zero time extrapolation which represented plasma radioactivity if distribution had occurred instantaneously after injection.

Plasma PBI $=5.8 \mu \mathrm{g}$. per $100 \mathrm{ml}$.

Zero time plasma radioactivity $=1,150 \mathrm{cpm}$ per $\mathrm{ml}$.

$$
\begin{gathered}
\frac{1,150}{5.8 / 100}=19,850 \mathrm{cpm} \text { per microgram of } \mathrm{PBI} \\
\frac{10,958,000 \mathrm{cpm} \text { injected }}{19,850 \mathrm{cpm} \text { per microgram of } \mathrm{PBI}}=552 \mu \mathrm{g} \text {. (EOI pool) }
\end{gathered}
$$

The product of the EOI pool and the turnover rate (k) gave the degradation rate in micrograms of organic iodine per day.

$552 \mu \mathrm{g}$. (EOI pool) $\times 10.4 \%$ per day $(\mathrm{k})=58 \mu \mathrm{g}$. I per day.

This figure represented the rates of formation and degradation, which are identical in a steady state with constant EOI pool. The calculations depend upon the assumption that a steady state existed, which appears reasonable in the absence of significant alterations in the clinical condition.

\section{Clinical material}

The subjects selected for study consisted of the following groups:

Normal. Eight healthy medical student volunteers.

Thyrotoxicosis. Six clinically typical cases, verified by abnormally high plasma PBI concentrations. C. S. was untreated. The other subjects except $M$. $O$. were receiving 15 drops of Lugol's solution daily, begun one or more weeks prior to study. M. O. was maintained nearly

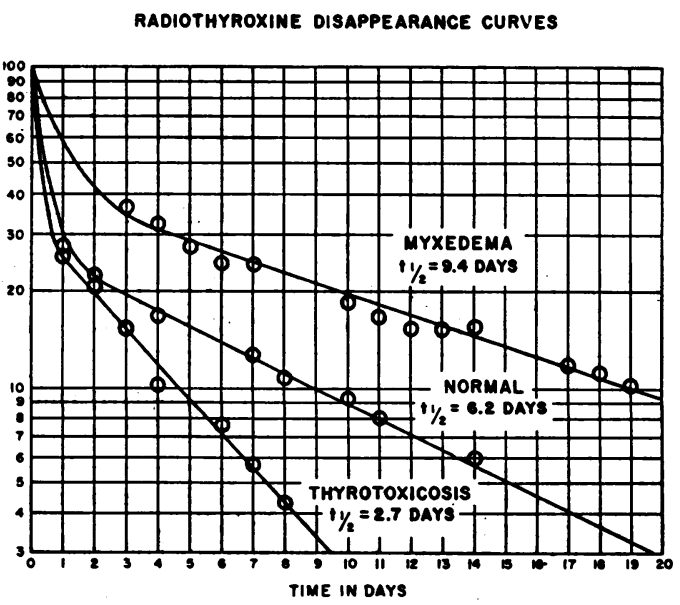

FIGURE 3

Semilogarithmic plot. Studies selected to illustrate kinetic differences. 
TABLE I

Data from radiothyroxine disappearance curves including values adjusted to $1.73 \mathrm{~m}^{2}$ surface area and 70 kg. body weight

\begin{tabular}{|c|c|c|c|c|c|c|c|c|c|c|c|c|c|c|c|}
\hline \multirow{3}{*}{ Condition } & \multirow{3}{*}{ Subject } & \multirow{3}{*}{ Sex } & \multirow{3}{*}{ Age } & \multirow{3}{*}{$\underset{(\text { kg. }}{\text { Wt. }}$} & \multirow{3}{*}{$\begin{array}{c}\text { Surface } \\
\text { area } \\
\left(m^{2}\right)\end{array}$} & \multirow{3}{*}{ BMR } & \multirow{3}{*}{$\begin{array}{c}\text { PBI* } \\
\text { (us. \%) }\end{array}$} & \multicolumn{8}{|c|}{ Kinetic and isotope dilution data } \\
\hline & & & & & & & & \multicolumn{2}{|c|}{$\begin{array}{l}\text { Kinetics of } \\
\text { disappearance }\end{array}$} & \multicolumn{3}{|c|}{$\begin{array}{c}\text { Extrathyroidal organic } \\
\text { iodine pool } \\
\text { (EOI) }\end{array}$} & \multicolumn{3}{|c|}{ Degradation rate } \\
\hline & & & & & & & & $\begin{array}{c}\text { Half- } \\
\text { time } \\
\text { (days) }\end{array}$ & $\begin{array}{l}\text { Turn- } \\
\text { over } \\
\text { rate } \mathbf{k} \\
(\%) \\
\text { day) }\end{array}$ & мg. & $\underset{m^{2}}{\mu 8 . / 1.73}$ & $\underset{\mathrm{kg} .}{\mathrm{\mu g} / 70}$ & $\underset{d a y}{\mu g . l}$ & $\mid \begin{array}{c}\mu 8 . / 1.73 \\
m^{2} / d a y\end{array}$ & $\underset{d a y}{\mu g . / 70} \mathrm{~kg} . /$ \\
\hline \multirow[t]{2}{*}{ Normal } & $\begin{array}{l}\text { JG } \\
\text { EG } \\
\text { AF } \\
\text { WC } \\
\text { JL } \\
\text { RL } \\
\text { GR } \\
\text { PR }\end{array}$ & $\begin{array}{l}\mathbf{M} \\
\mathbf{M} \\
\mathbf{M} \\
\mathbf{M} \\
\mathbf{M} \\
\mathbf{M} \\
\mathbf{M} \\
\mathbf{M}\end{array}$ & $\begin{array}{l}23 \\
23 \\
23 \\
23 \\
26 \\
24 \\
24 \\
24\end{array}$ & $\begin{array}{l}68.2 \\
75.0 \\
79.5 \\
72.8 \\
81.8 \\
79.1 \\
70.5 \\
84.1\end{array}$ & $\begin{array}{l}1.81 \\
1.94 \\
2.00 \\
1.88 \\
2.06 \\
2.03 \\
1.81 \\
2.04\end{array}$ & & $\begin{array}{l}5.2 \\
5.0 \\
7.2 \\
7.2 \\
5.7 \\
5.4 \\
7.0 \\
6.9\end{array}$ & $\begin{array}{l}6.2 \\
5.7 \\
7.7 \\
7.0 \\
7.0 \\
6.1 \\
7.4 \\
6.2\end{array}$ & $\begin{array}{r}11.2 \\
12.2 \\
9.0 \\
9.9 \\
9.9 \\
11.4 \\
9.4 \\
11.2\end{array}$ & $\begin{array}{l}458 \\
423 \\
625 \\
455 \\
587 \\
507 \\
590 \\
741\end{array}$ & $\begin{array}{l}440 \\
378 \\
544 \\
419 \\
493 \\
431 \\
566 \\
629\end{array}$ & $\begin{array}{l}472 \\
395 \\
550 \\
437 \\
505 \\
451 \\
584 \\
615\end{array}$ & $\begin{array}{l}\mathbf{5 1} \\
\mathbf{5 2} \\
\mathbf{5 6} \\
\mathbf{4 5} \\
\mathbf{5 8} \\
\mathbf{5 8} \\
\mathbf{5 5} \\
\mathbf{8 3}\end{array}$ & $\begin{array}{l}49 \\
46 \\
49 \\
41 \\
49 \\
49 \\
53 \\
71\end{array}$ & $\begin{array}{l}53 \\
48 \\
49 \\
43 \\
50 \\
52 \\
54 \\
69\end{array}$ \\
\hline & \multicolumn{7}{|c|}{$\begin{array}{r}\text { Mean } \\
\text { Standard Deviation } \\
\text { Standard Error of Mean }\end{array}$} & $\begin{array}{l}6.7 \\
0.7 \\
0.3\end{array}$ & $\begin{array}{r}10.5 \\
1.1 \\
0.4\end{array}$ & $\begin{array}{r}548 \\
107 \\
38\end{array}$ & $\begin{array}{r}488 \\
86 \\
31\end{array}$ & $\begin{array}{r}501 \\
77 \\
27\end{array}$ & $\begin{array}{r}57 \\
11 \\
4.0\end{array}$ & $\begin{array}{r}51 \\
9 \\
3.1\end{array}$ & $\begin{array}{r}52 \\
8 \\
2.7\end{array}$ \\
\hline $\begin{array}{l}\text { Hospital } \\
\text { control }\end{array}$ & $\mathbf{R R}$ & $\mathbf{M}$ & 59 & 65.5 & 1.87 & -9 & 5.8 & 6.7 & 10.4 & 552 & 511 & 590 & 58 & 54 & 62 \\
\hline \multirow[t]{2}{*}{ Myxedema } & $\begin{array}{l}\text { MA } \\
\text { CC } \\
\text { HL } \\
\text { HR-1 } \\
\text { HR-2† } \\
\text { CL } \\
\text { MM } \\
\text { CH } \\
\text { FK }\end{array}$ & $\begin{array}{l}F \\
F \\
F \\
F \\
F \\
M \\
F \\
F \\
F\end{array}$ & $\begin{array}{l}58 \\
68 \\
40 \\
61 \\
62 \\
74 \\
58 \\
86 \\
69\end{array}$ & $\begin{array}{r}43.3 \\
60.9 \\
103.6 \\
63.2 \\
46.4 \\
69.5 \\
89.0 \\
77.3 \\
61.4\end{array}$ & $\begin{array}{l}1.44 \\
1.60 \\
2.12 \\
1.66 \\
1.47 \\
1.78 \\
2.03 \\
1.94 \\
1.59\end{array}$ & $\begin{array}{l}-28 \\
-44 \\
-24 \\
-42 \\
-47 \\
-49\end{array}$ & $\begin{array}{l}2.0 \\
2.3^{*} \\
1.9 \\
1.0 \\
2.4^{*} \\
2.2 \\
\ddagger \\
2.2 \\
2.0\end{array}$ & $\begin{array}{r}9.7 \\
9.3 \\
7.9 \\
9.3 \\
9.4 \\
12.6 \\
10.3 \\
8.3 \\
10.6\end{array}$ & $\begin{array}{l}7.1 \\
7.5 \\
8.8 \\
7.5 \\
7.4 \\
5.5 \\
6.7 \\
8.4 \\
6.5\end{array}$ & $\begin{array}{l}161 \\
276 \\
233 \\
141 \\
233 \\
292 \\
\\
264 \\
306\end{array}$ & $\begin{array}{l}193 \\
298 \\
191 \\
146 \\
274 \\
283 \\
\\
235 \\
334\end{array}$ & $\begin{array}{l}261 \\
317 \\
158 \\
157 \\
352 \\
295 \\
\\
240 \\
349\end{array}$ & $\begin{array}{l}12 \\
21 \\
20 \\
11 \\
17 \\
16 \\
\\
22 \\
20\end{array}$ & $\begin{array}{l}14 \\
23 \\
16 \\
11 \\
20 \\
16 \\
\\
20 \\
22\end{array}$ & $\begin{array}{l}19 \\
24 \\
14 \\
12 \\
26 \\
16 \\
\\
20 \\
23\end{array}$ \\
\hline & \multicolumn{7}{|c|}{$\begin{array}{r}\text { Mean } \\
\text { Standard Deviation } \\
\text { Standard Error of Mean }\end{array}$} & $\begin{array}{l}9.7 \\
1.4 \\
0.5\end{array}$ & $\begin{array}{l}7.3 \\
1.1 \\
0.4\end{array}$ & $\begin{array}{r}238 \\
60 \\
21\end{array}$ & $\begin{array}{r}244 \\
64 \\
22\end{array}$ & $\begin{array}{r}266 \\
77 \\
27\end{array}$ & $\begin{array}{r}17 \\
4 \\
1.3\end{array}$ & $\begin{array}{r}18 \\
4 \\
1.3\end{array}$ & $\begin{array}{r}19 \\
5 \\
1.8\end{array}$ \\
\hline \multirow[t]{2}{*}{$\begin{array}{l}\text { Thyro- } \\
\text { toxicosis }\end{array}$} & $\begin{array}{l}\text { RD } \\
\text { LD } \\
\text { LS } \\
\text { CS\& } \\
\text { MB } \\
\text { MO\| }\end{array}$ & $\begin{array}{l}F \\
F \\
F \\
M \\
F \\
F\end{array}$ & $\begin{array}{l}31 \\
17 \\
29 \\
58 \\
47 \\
54\end{array}$ & $\begin{array}{l}51.8 \\
52.3 \\
54.6 \\
60.2 \\
42.3 \\
56.8\end{array}$ & $\begin{array}{l}1.54 \\
1.52 \\
1.52 \\
1.76 \\
1.37 \\
1.60\end{array}$ & $\begin{array}{r}+17 \\
+68 \\
+74 \\
+32 \\
+4\end{array}$ & $\begin{array}{r}13.6 \\
14.6 \\
11.4^{*} \\
8.5 \\
13.6 \\
8.8\end{array}$ & $\begin{array}{l}4.0 \\
5.2 \\
3.7 \\
2.7 \\
4.7 \\
5.8\end{array}$ & $\begin{array}{l}17.3 \\
13.7 \\
18.7 \\
25.6 \\
14.7 \\
11.9\end{array}$ & $\begin{array}{r}974 \\
954 \\
1,222 \\
1,248 \\
880 \\
845\end{array}$ & $\begin{array}{r}1,094 \\
1,088 \\
1,393 \\
1,223 \\
1,109 \\
913\end{array}$ & $\begin{array}{l}1,315 \\
1,278 \\
1,564 \\
1,448 \\
1,461 \\
1,039\end{array}$ & $\begin{array}{l}169 \\
127 \\
229 \\
320 \\
129 \\
101\end{array}$ & $\begin{array}{l}190 \\
145 \\
261 \\
314 \\
163 \\
109\end{array}$ & $\begin{array}{l}228 \\
170 \\
293 \\
371 \\
214 \\
124\end{array}$ \\
\hline & \multicolumn{7}{|c|}{$\begin{array}{r}\text { Mean } \\
\text { Standard Deviation } \\
\text { Standard Error of Mean }\end{array}$} & $\begin{array}{l}4.4 \\
1.1 \\
0.5\end{array}$ & $\begin{array}{r}16.9 \\
5.0 \\
2.1\end{array}$ & $\begin{array}{r}1,021 \\
173 \\
70.9\end{array}$ & $\begin{array}{r}1,137 \\
160 \\
65\end{array}$ & $\begin{array}{r}1,351 \\
185 \\
75.8\end{array}$ & $\begin{array}{r}179 \\
82 \\
34\end{array}$ & $\begin{array}{r}197 \\
77 \\
35\end{array}$ & $\begin{array}{r}233 \\
88 \\
36\end{array}$ \\
\hline \multirow[t]{2}{*}{$\begin{array}{c}\text { Hyper- } \\
\text { metabolism }\end{array}$} & $\begin{array}{l}\text { RV } \\
\text { LP } \\
\text { EL } \\
\text { PN } \\
\text { FD }\end{array}$ & $\begin{array}{l}\mathbf{M} \\
\mathbf{M} \\
\mathbf{M} \\
\mathbf{M} \\
\mathbf{M}\end{array}$ & $\mid \begin{array}{l}66 \\
57 \\
52 \\
55 \\
21\end{array}$ & $\begin{array}{l}73.2 \\
74.5 \\
42.7 \\
65.9 \\
69.5\end{array}$ & $\begin{array}{l}1.80 \\
1.88 \\
1.46 \\
1.68 \\
1.88\end{array}$ & $\begin{array}{r}+37 \\
+31 \\
+39 \\
+120 \\
+110\end{array}$ & $\begin{array}{l}6.1 \\
5.9 \\
4.5 \\
5.6 \\
4.8\end{array}$ & $\begin{array}{l}5.2 \\
6.2 \\
5.2 \\
5.4 \\
3.9\end{array}$ & $\begin{array}{l}13.3 \\
11.2 \\
13.3 \\
12.8 \\
17.8\end{array}$ & $\begin{array}{r}810 \\
1,124 \\
605 \\
540 \\
686\end{array}$ & $\begin{array}{r}778 \\
1,034 \\
717 \\
556 \\
631\end{array}$ & $\begin{array}{r}778 \\
1,056 \\
992 \\
572 \\
693\end{array}$ & $\begin{array}{r}108 \\
126 \\
81 \\
69 \\
122\end{array}$ & $\begin{array}{r}104 \\
116 \\
96 \\
71 \\
112\end{array}$ & $\begin{array}{r}104 \\
118 \\
132 \\
73 \\
123\end{array}$ \\
\hline & \multicolumn{7}{|c|}{$\begin{array}{r}\text { Mean } \\
\text { Standard Deviation } \\
\text { andard Error of Mean }\end{array}$} & $\begin{array}{l}5.2 \\
0.8 \\
0.4\end{array}$ & $\begin{array}{r}13.7 \\
2.5 \\
1.1\end{array}$ & $\begin{array}{l}753 \\
230 \\
103\end{array}$ & $\begin{array}{r}743 \\
183 \\
82\end{array}$ & $\begin{array}{r}818 \\
203 \\
91\end{array}$ & $\begin{array}{r}101 \\
25 \\
11\end{array}$ & $\begin{array}{r}100 \\
18 \\
8\end{array}$ & $\begin{array}{r}110 \\
23 \\
10\end{array}$ \\
\hline
\end{tabular}

* Butanol extractable iodine (BEI) performed rather than PBI in CC, HR-2, and LS to avoid interference from previously administered inorganic iodine.

$+\mathrm{HR}-2$. Second study on subject HR, performed four months after cessation of desiccated thyroid therapy.

+ MM. Falsely high PBI, attributed to contamination, prevented calculations from kinetic data.

\$ CS. No inorganic iodine administered (Figure 2), in contrast to other thyrotoxic subjects who received 15 drops of Lugol's solution daily.

IMO. Lugol's solution was not administered. Patient was maintained nearly euthyroid with antithyroid medications begun 3 weeks before and continued during the study (Tapazole (\$) $40 \mathrm{mg}$. daily, later propylthiouracil $400 \mathrm{mg}$. daily).

I PN. Initial high fever $\left(104^{\circ} \mathrm{F}\right.$.) subsided on administration of regimen of hydrocortisone $120 \mathrm{mg}$. daily and triethylene melamine (T.E.M.) $5 \mathrm{mg}$. daily. 
euthyroid for three weeks prior to and throughout the study with Tapazole(\$), later with propylthiouracil.

Myxedema. Eight clinically typical cases, verified by abnormally low plasma PBI concentrations and by BMR in most instances. Cases H. R. and C. L. were previously untreated. The other patients had received no thyroid replacement therapy for three or more months.

Hypermetabolism without endocrine disease. Four cases of leukemia with fever and one case of urinary tract infection with fever (R. V.). All patients had temperature elevations reaching $104^{\circ} \mathrm{F}$. and all had elevated rates of metabolism but normal plasma PBI concentration.

Hospital control. One case of multiple sclerosis with no evidence of endocrine disease and with normal plasma PBI concentration.

In previous studies $(1,6)$ employing the $I^{121}$ label for turnover rates, Lugol's solution or potassium iodide had been administered to minimize thyroid uptake and promote urinary excretion of $\mathrm{I}^{191}$ liberated on degradation of the labeled compound. This precaution of iodine prefeeding to prevent reutilization of the label and its reappearance in the circulation as newly formed radiothyroxine was not carried out by Ingbar and Freinkel (2) whose data show no evidence of significant interference from reutilization, except in hyperthyroid subjects. Sufficient reutilization to affect radiothyroxine disappearance curves significantly would not be expected in myxedema because of negligible thyroid activity, or even in normals, because of mathematical considerations of the turnover and magnitude of the thyroidal iodine pool (3). This inference receives support from the data of $R$. R., the hospital control subject with multiple sclerosis; the addition of potassium iodide midway through the study produced no visible change in the disappearance curve (Figure 1). Other similar findings, not included in the present report, bear out this conclusion. Moreover, the other euthyroid control subjects in the present work received no added iodine, and had disappearance curves which did not differ significantly from those in the euthyroid series previously reported (1), where iodine was administered.

On the other hand, the curve obtained in the hyperthyroid subject C. S. studied without iodine prefeeding shows a break after the eighth day (Figure 2). The subsequent flattening of the curve was attributed to secretion of newly synthesized labeled hormone which evidently may be quite appreciable in untreated thyrotoxicosis. Consequently, the other thyrotoxic subjects, except M. O., were given 15 drops of Lugol's solution daily prior to and during the studies, and must be considered in partial though slight remission. Subject M. O. was maintained nearly euthyroid for three weeks prior to and throughout the study with Tapazole ${ }^{8}$, later propylthiouracil. The euthyroid and myxedematous subjects were not given added iodine.

\section{RESULTS}

The disappearance curves (Figure 3 ) showed a slower than normal rate of fall in myxedema, and
TABLE II

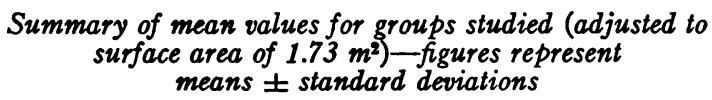

\begin{tabular}{lrrrr}
\hline \multicolumn{1}{c}{ Group } & $\begin{array}{c}\text { EOI pool } \\
(\mu g .)\end{array}$ & \multicolumn{1}{c}{$\begin{array}{c}\text { Turnover } \\
\text { rate } \\
(\% / \text { day })\end{array}$} & $\begin{array}{c}\text { Degrada- } \\
\text { tion rate } \\
(\mu g .1 / \text { day })\end{array}$ \\
\hline Normal & $488 \pm 86$ & $10.5 \pm 1.1$ & $51 \pm 9$ \\
Myxedema & $244 \pm 64$ & $7.3 \pm 1.0$ & $18 \pm 4$ \\
Thyrotoxicosis & $1,137 \pm 160$ & $16.9 \pm 5.0$ & $197 \pm 35$ \\
Hypermetabolism & $743 \pm 183$ & $13.7 \pm 2.5$ & $100 \pm 18$ \\
\hline
\end{tabular}

an accelerated turnover rate in thyrotoxicosis. The extrathyroidal organic iodine (EOI) pools were diminished in myxedema and increased in thyrotoxicosis (Tables I and II).

The absolute degradation rates, being the products of the pools and turnovers, showed even wider divergences between the different groups.

Within the hyperthyroid group, the highest values occurred in C. S., the untreated patient, while the lowest were seen in M. O., the patient who was maintained nearly euthyroid with antithyroid medication.

The cases of hypermetabolism without endocrine disease exhibited degradation rates lower than the thyrotoxic patients but still significantly greater than normal. The highest values in a normal subject, P. R., approximated the lowest rate in a hypermetabolic leukemic patient, $P$. $N$. In the latter case, hydrocortisone and triethylene melamine (T.E.M.) therapy were instituted shortly after the start of the study, and the temperature declined from $104^{\circ} \mathrm{F}$. to $100^{\circ} \mathrm{F}$; ; whether or not the BMR declined correspondingly was not determined because of gingival bleeding.

The short term effect of massive thyroid replacement therapy was investigated to determine whether it would alter the slowly falling disappearance curve in myxedema. Large intravenous doses of 1-thyroxine resulting in marked elevation of plasma PBI failed to produce evident change in curves in studies continued 7 to 10 days after therapy (Figure 4 and Table III). The amounts of thyroxine administered were sufficient to increase markedly the EOI pool. Because of its prompt calorigenic effect $(7,8)$ L-triiodothyronine ${ }^{4}$ was given by mouth either alone or con-

4 L-triiodothyronine was supplied through the courtesy of Smith, Kline and French Laboratories, Philadelphia, Pa. 


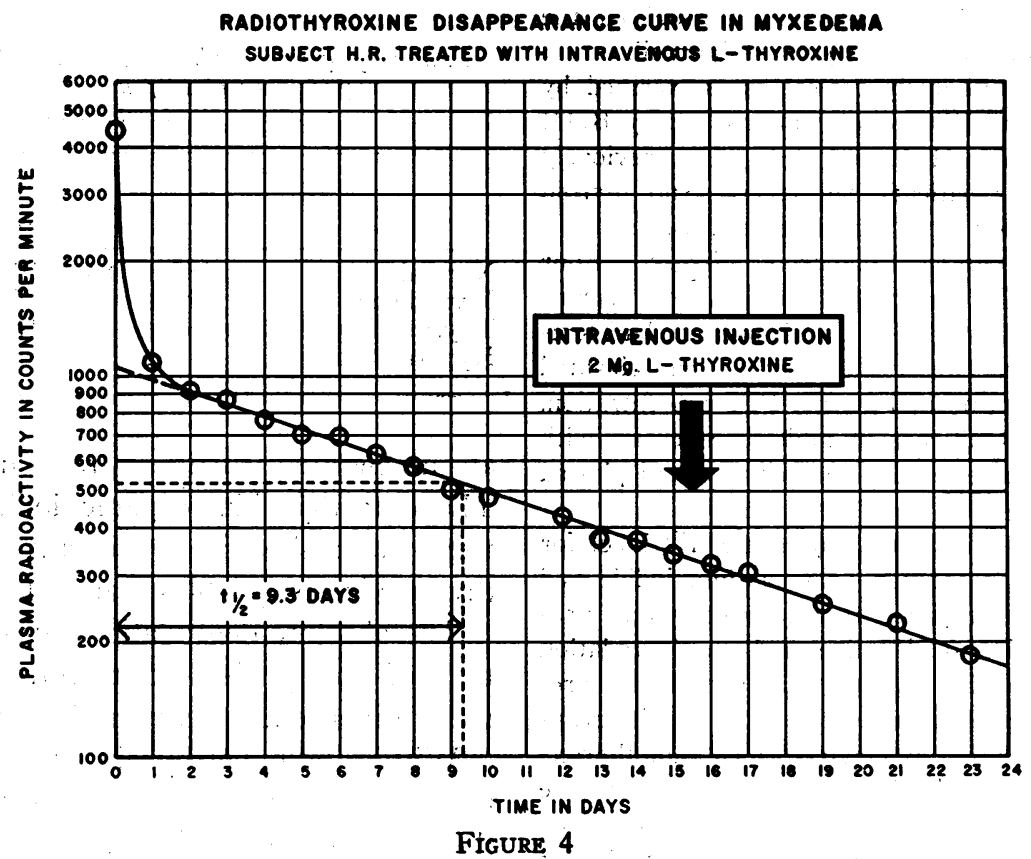

currently with intravenous thyroxine, again without effect upon radioactivity disappearance curves, although the patients exhibited definite clinical responses.

\section{DISCUSSION}

The degradation rates referred to in the present study are so designated, implying rates of removal of hormone from the extrathyroidal pool without

TABLE III

Treatment of myxedema patients *

\begin{tabular}{|c|c|c|c|c|}
\hline Patient & $\underset{\text { (micrograms) }}{\text { EOI pool }}$ & Therapy & $\begin{array}{c}\text { Maximal rise in } \\
\text { PBI above baseline } \\
\text { (ug.|100 ml.) }\end{array}$ & $\begin{array}{c}\text { Maximal rise } \\
\text { in BMR above } \\
\text { baseline }\end{array}$ \\
\hline M. A. & 161 & $\begin{array}{l}1 \mathrm{mg} . \mathrm{T} 4 ; \\
1.45 \mathrm{mg} . \mathrm{T} 3 \text { over } \\
\text { course of } 8 \text { days }\end{array}$ & 12.4 & \\
\hline C. C. & 276 & $\begin{array}{l}0.825 \mathrm{mg} . \mathrm{T} 3 \text { over } \\
\text { course of } 7 \text { days }\end{array}$ & 0.0 & \\
\hline H. L. & 233 & $\begin{array}{l}2 \mathrm{mg} . \mathrm{T} 4 ; \\
1.65 \mathrm{mg} . \mathrm{T} 3 \text { over } \\
\text { course of } 10 \text { days }\end{array}$ & 19.5 & \\
\hline H. R. -1 & 141 & $2 \mathrm{mg} . \mathrm{T} 4$ & Contaminated & +40 \\
\hline H. R. -2 & 233 & $\begin{array}{l}2 \mathrm{mg} . \mathrm{T} 4 ; \\
1.45 \mathrm{mg} . \mathrm{T} 3 \text { over } \\
\text { course of } 9 \text { days }\end{array}$ & $>8.8 t$ & \\
\hline C. $\mathrm{L}$. & 292 & $\begin{array}{l}2 \mathrm{mg} . \mathrm{T} 4 ; \\
1 \mathrm{mg} \text {. T3; } \\
0.5 \mathrm{mg} . \mathrm{T} 3 \text { (3 days later) }\end{array}$ & 26.2 & +33 \\
\hline M. M. & & $2 \mathrm{mg} . \mathrm{T} 4$ & 23.7 & . \\
\hline F. K. & 306 & $\begin{array}{l}2 \mathrm{mg} \text {. T3 over } \\
\text { course of } 7 \text { days }\end{array}$ & Not determined & \\
\hline
\end{tabular}

* T4 represents single intravenous injection of L-thyroxine. Thyroxine is 65.4 per cent iodine by weight. T3 represents L-triodothyronine by mouth, either in a single dose or aver the course of several days as noted. Triiodothyronine is $\mathbf{5 8 . 5}$ per cent iodine by weight.

$\dagger$ The increase of 8.8 was obtained on plasma drawn the following day, rather than 10 minutes after intravenous injection of thyroxine, as in the other cases. 
specification of the precise pathways of removal. The calculations, in all except three subjects, were based upon plasma PBI determinations, which give slightly higher values than BEI, evidently a more accurate measurement of circulating thyroid hormone (5). The general relationship between level of thyroid function and rate of peripheral degradation of hormone is apparent from the present study as well as the work of Berson and Yalow (3) and of Ingbar and Freinkel (2).

Figure 5 illustrates that degradation rate was related to the plasma PBI concentration, the points showing a considerable scatter in the higher ranges. This scatter was not greatly improved by employing a log-log plot of degradation rate as a function of the square of $\mathrm{PBI}$ concentration (3).

It does not necessarily follow, however, that the rate of degradation is controlled directly by the PBI concentration as a mass action effect. On the contrary, the failure of large doses of thyroxine, triiodothyronine, or both to alter the disappearance curve in myxedema suggests that, under given circumstances, a fixed proportion of the extrathyroidal organic iodine pool is removed per day, even when the pool is acutely increased by intravenous thyroxine. This fixed rate persisted, even with elevation of the BMR to normal in short term triiodothyronine experiments. Whether the kinetics would be altered by several weeks' or months' maintenance in the euthyroid state remains to be determined. It is conceivable that the mechanism for degrading thyroxine might, like the changes in the integument, require many months of replacement therapy before appreciable reversion to normal. ${ }^{5}$

The unaltered disappearance curves (and hence unaltered daily fractional removal rates) observed after large intravenous doses of thyroxine indicated a markedly elevated absolute amount of hormone degraded, since the administered thyroxine greatly exceeded the amount originally pres-

5 Addendum since completion of paper: Ingbar and Freinkel have observed (personal communication) that the slow thyroxine turnover of myxedematous subjects has increased to normal after several months' maintenance in the euthyroid state with desiccated thyroid therapy. Moreover, they have demonstrated increased thyroxine turnover in normal subjects maintained hypermetabolic $(B M R+25$ to +30$)$ for two to three months with triiodothyronine.
RELATION BETWEEN DEGRADATION RATE AND P B I

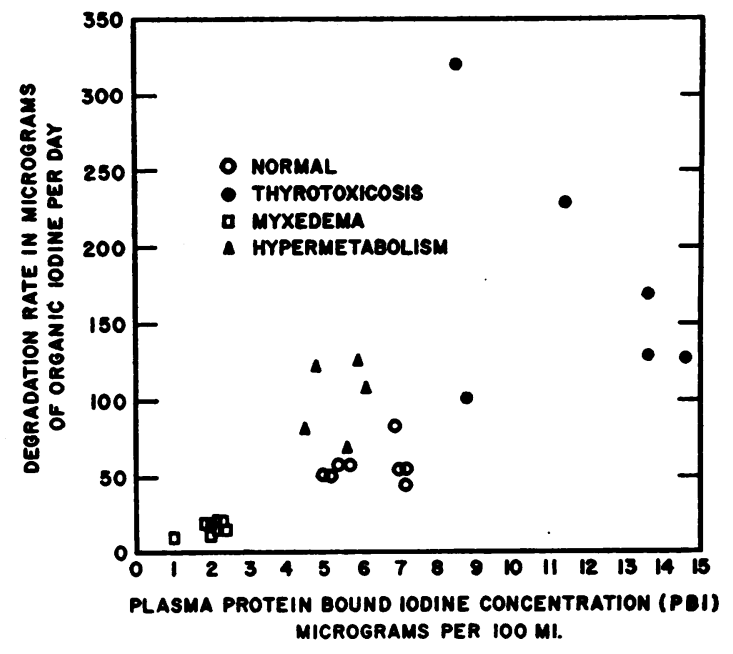

Frgure 5

ent (cf. EOI pools, Table III). This finding of unchanged kinetics despite markedly increased pool size and serum concentration of hormone is analogous, perhaps, to the observation by Hellman, Bradlow, Adesman, Fukushima, Kulp, and Gallagher that hydrocortisone-4-C $\mathrm{C}^{14}$ administered to an oöphorectomized adrenalectomized patient disappeared at the same rate, whether given as a tracer or with $100 \mathrm{mg}$. hydrocortisone (9).

Ingbar and Freinkel (10) have reported the converse finding, namely, persistently elevated degradation rates in thyrotoxic patients several months after surgical or antithyroid therapy with attainment of the euthyroid state. In the present study patient M. O. had experienced almost complete remission of her thyrotoxicosis under treatment with antithyroid drugs, but showed a significantly elevated degradation rate, although it was the lowest of the hyperthyroid group.

In considering radiothyroxine turnover studies, attention should be given to the possibility that thyroxine may exert its metabolic effect only after conversion to triiodothyronine in the peripheral tissues. Gross and Leblond (11) demonstrated that "unknown l" (later shown to be triiodothyronine) was formed from thyroxine in peripheral tissues of thyroidectomized animals. Pitt-Rivers, Stanbury, and Rapp (12) found labeled triiodothyronine in the plasma of athyreotic patients after administration of $\mathrm{I}^{131}$-labeled thyroxine. Albright, Larson, and Tust (13) showed 
in vitro conversion of thyroxine to triiodothyronine by kidney slices. These observations are compatible with the theory that this may be a major route of removal of circulating thyroxine. Larson, Tomita, and Albright (14) have shown that kidney slices from thyroidectomized rats convert thyroxine to triiodothyronine more slowly than slices from normal rats, while the kidneys from thyrotoxic animals (fed desiccated thyroid or exposed to cold) accomplished this conversion at an accelerated rate. The postulated adaptive enzyme system for thyroxine deiodination may well have relevance for the disappearance curves of the present study.

An additional factor which cannot be excluded at this time is possible differences in thyroxine binding protein, a problem which requires further study.

Elevated degradation rates occurred in the hypermetabolic subjects with normal plasma PBI concentration. This finding of dissociation between PBI and degraelation rate would argue further against the assumption that the rate of removal of hormone is a mass action phenomenon determined directly by PBI concentration. Moreover, Castor and Beierwaltes (15) have reported depression of PBI concentration in human subjects made hypermetabolic by administration of dinitrophenol for two days, an observation which could be interpreted as acutely accelerated thyroxine degradation. In the absence of more extensive information with regard to mechanisms of hormone removal, the data would suggest that peripheral tissue metabolism, or some function thereof, has major importance in determining hormone degradation rate.

\section{SUMMARY}

1. The rate of peripheral degradation of circulating thyroid hormone was studied with $\mathrm{I}^{131}$-labeled L-thyroxine in normal subjects, patients with thyroid disease, and hypermetabolic patients without endocrine disease (leukemia, fever).

2. After intravenous injection of a tracer amount of radiothyroxine the rate of disappearance of plasma radioactivity was determined.

3. The slow exponential component of the disappearance curve was interpreted as the rate of metabolic degradation.
4. The extrathyroidal organic iodine (EOI) pools calculated by the isotope dilution principle were diminished in myxedema and increased in thyrotoxicosis, as compared with the normals.

5. The turnover rates of extrathyroidal hormone obtained from the half-times of disappearance were slower than normal in myxedema, and accelerated in thyrotoxicosis.

6. The absolute organic iodine degradation rates, being the products of the pools and turnovers, showed even wider divergences between the different groups. The mean values \pm standard deviation in micrograms of iodine per day (adjusted to $1.73 \mathrm{~m}^{2}$ surface area) were as follows :

$\begin{array}{lc}\text { Normal } & 51 \pm 9 \\ \text { Myxedema } & 18 \pm 4 \\ \text { Thyrotoxicosis } & 197 \pm 35 \\ \text { Hypermetabolism } & 100 \pm 18\end{array}$

7. The hypermetabolic subjects without endocrine disease had increases in pools, turnovers, and degradation rates, although less pronounced than in thyrotoxicosis. The elevated values in nonspecific hypermetabolism suggested that peripheral tissue metabolism, or some function thereof, has a major role in determining hormone degradation rate.

8. Administration of large amounts of thyroxine or triiodothyronine or both to myxedematous subjects failed to alter the shape of the disappearance curve. This indicated turnover of a fixed proportion of the EOI pool daily, during short term studies, despite marked elevation of the plasma PBI concentration, enlargement of the EOI pool, and increase in the absolute organic iodine degradation rate.

\section{REFERENCES}

1. Sterling, K., Lashof, J. C., and Man, E. B., Disappearance from serum of $I^{131}$-labeled 1-thyroxine and 1-triiodothyronine in euthyroid subjects. J. Clin. Invest., 1954, 33, 1031.

2. Ingbar, S. H., and Freinkel, N., Simultaneous estimation of rates of thyroxine degradation and thyroid hormone synthesis. J. Clin. Invest., 1955, 34, 808.

3. Berson, S. A., and Yalow, R. S., Quantitative aspects of iodine metabolism. The exchangeable organic iodine pool, and the rates of thyroidal secretion, peripheral degradation and fecal excretion of endogenously synthesized organically bound iodine. J. Clin. Invest., 1954, 33, 1533. 
4. Barker, S. B., Humphrey, M. J., and Soley, M. H., The clinical determination of protein-bound iodine. J. Clin. Invest., 1951, 30, 55.

5. Man, E. B., Kydd, D. M., and Peters, J. P., Butanolextractable iodine of serum. J. Clin. Invest., 1951, 30, 531.

6. Sterling, K., The turnover rate of serum albumin in man as measured by $\mathrm{I}^{121}$-tagged albumin. J. Clin. Invest., 1951, 30, 1228.

7. Asper, S. P., Jr., Selenkow, H. A., and Plamondon, C. A., A comparison of the metabolic activities of $3,5,3^{\prime}-1$-triiodothyronine versus 1-thyroxine in myxedema. Bull. Johns Hopkins Hosp., 1953, 93, 164.

8. Blackburn, C. M., McConahey, W. M., Keating, F. R., Jr., and Albert, A., Calorigenic effects of single intravenous doses of 1-triiodothyronine and 1-thyroxine in myxedematous persons. J. Clin. Invest., 1954, 33, 819.

9. Hellman, L., Bradlow, H. L., Adesman, J., Fukushima, D. K., Kulp, J. L., and Gallagher, T. F., The fate of hydrocortisone-4-C $\mathrm{C}^{4 /}$ in man. J. Clin. Invest., 1954, 33, 940.
10. Ingbar, S. H., and Freinkel, N., An abnormality of the peripheral metabolism of thyroxine in patients with treated Graves' disease: The syndrome of euthyroidism associated with thyroidal hyperfunction. J. Clin. Invest., 1955, 34, 914.

11. Gross, J., and Leblond, C. P., Metabolites of thyroxine. Proc. Soc. Exper. Biol. \& Med., 1951, 76, 686.

12. Pitt-Rivers, R., Stanbury, J. B., and Rapp, B., Conversion of thyroxine to $3-5-3^{\prime}$-triiodothyronine in vivo. J. Clin. Endocrinol. \& Metab., 1955, 15, 616.

13. Albright, E. C., Larson, F. C., and Tust, R. H., In vitro conversion of thyroxine to triiodothyronine by kidney slices. Proc. Soc. Exper. Biol. \& Med., 1954, 86, 137.

14. Larson, F. C., Tomita, K., and Albright, E. C., The deiodination of thyroxine to triiodothyronine by kidney slices of rats with varying thyroid function. Endocrinology, 1955, 57, 338.

15. Castor, C. W., and Beierwaltes, W. H., Depression of serum protein bound iodine levels in man with dinitrophenol. J. Clin. Endocrinol. \& Metab., 1955, $15,862$. 